\title{
An Exploratory Study Of The Determinants Of Tuition For Online MBA Programs
}

Hooman Estelami, Fordham University, USA Zixin Mao, Fordham University, USA

\begin{abstract}
The number of online MBA programs has increased in recent years while the demand is stabilizing. In light of this trend, the pricing of online MBA programs is an important issue for university administrators and policy makers, who are concerned about program competitiveness and public access to higher education. This study examines the drivers of tuition levels for online MBA programs. Utilizing data from 149 programs in the United States, the influence of various variables on tuition levels is empirically established. The findings indicate that residency and GMAT requirements, as well as enrollment size and student-to-faculty ratio, are important determinants of tuition for online MBA programs. The empirical framework presented in this paper allows university administrators to establish if the tuitions charged for their programs are consistent with market norms, and thereby determine the potential need for adjustment in tuition levels.
\end{abstract}

Keywords: Online Education; Online MBA; Tuition; Pricing

\section{INTRODUCTION}

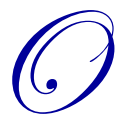

nline higher education has been growing worldwide, especially evident in the context of MBA and business master's programs. Between 2012 and 2016, the number of AACSB accredited universities offering online MBA programs increased from 97 to 140 (Nelson, 2016). According to Google Trends statistics, while the number of searches for "online MBA" has remained stable during the last decade, the number of searches for "online MBA cost" has steadily increased by $200 \%$ for the same time period. Amidst the growing interest in the cost of online MBAs, disagreement exists as to how pricing of online education and specifically online business degrees should be done (Byrd, Roufagala, \& Mixon, 2015, Straumsheim, 2017, Poulin \& Straut, 2017, Liberman, 2018). There is a growing need to understand the pricing of these programs. As the offering of online MBA programs becomes more prominent, and the technology through which distance education is delivered matures, the tuition norms for online MBA programs evolve. Therefore, profiling the determinants of the tuition for online MBA degrees is an important question for university administrators, as well as public policy advocates concerned about public access to higher education.

Given the absence of current studies on the tuition determinants for online MBA degrees, the focus of this study will be to profile current online MBA tuition levels, and to empirically and statistically identify the factors that determine them. Using online MBA tuition data for programs in the United States, a pricing model is developed to establish how tuition levels are determined. Specifically, the roles of the following six variables are studied: private vs. public nature of the university, size of the student population at the university, the student-to-faculty ratio, whether or not there is a GMAT requirement for applying to the MBA program, on-campus residency requirement, and finally the accreditation status of the program. Data from a total of 149 online MBA programs are statistically examined to quantify the role of the above factors, and the findings indicate that the combined effects of the above factors can determine tuition levels with a high level of accuracy.

\section{BACKGROUND}

Ever since these early forms of distance education, the common theme has been, and continues to be, to achieve a high degree of efficiency from both the institutional and student perspectives (Rumble, 2009). These efficiencies are realized, for example, through the relaxation of logistical constraints of where the student and instructor are located at the time of instruction, reduced reliance on physical infrastructure, the ability to scale up programs to serve large 
student bodies, and other factors that ease and facilitate the learning process. The transformation of these efficiency gains in terms of the cost structure for the institution and the tuitions charged from the students has not always been apparent due to the presence of various other costs such as faculty development, information technology costs, and variations in the online instructional approaches used in various universities. At a time when debates around the affordability of growing higher education student loans have taken center-stage in the national psyche, it is important for universities and colleges to be fair and methodical in how they determine the costs for their online programs, in order to provide the public with access to higher education while maintaining institutional competitiveness and profitability.

Current studies on the determinants of tuition for online MBA programs are non-existent, and past research in this area is for the most part dated, while other studies fail to directly relate to the context of online MBA tuition pricing. Most of the formal studies of this issue date back nearly a decade (Eaton, 2006; Estelami \& Rezvani, 2011; Smith \& Bramble, 2008), indicating that certain factors that characterize an online MBA program can influence tuition levels. For example, the profit orientation of a university was found to influence online MBA tuitions, such that programs which are non-profit are typically found to have lower tuition levels. Research has also shown that enrollment size and funding source of higher education institutions may be correlated with tuition levels (Wang, 2015). In addition, the endorsement of a program by an accreditation agency can positively influence its attractiveness to prospective students (Eaton, 2006). However, most of the past studied, in addition to being dated and therefore not capturing the current dynamics in the online MBA market, have only explored the effects of a limited number of variables.

\section{DETERMINANTS OF ONLINE MBA TUITION LEVELS}

The tuition of any online program may be affected by a series of variables that characterize the institution, as well as variables that determine the student requirements for entering or completing the program. Among the variables that describe an educational institution are the size of the student population, the student-to-faculty ratio, the accreditation status of the institution, and the public versus private status of the institution. The tuition level of an online program can also be affected by the requirements and demands made of prospective and enrolled students, such as whether or not there are GMAT requirements for applying to the program, and whether the students are required to attend any on-campus residency events to complete their online degree. In what follows, we will examine the potential role that the above factors can have on online MBA tuition levels, and then present the results of an empirical study.

\section{The Effects of the Size of Student Population}

It can be argued that larger educational institutions experience greater economies of scale. Larger scale of operations translates into greater efficiency gains due to the use of shared resources and lower cost of delivering the educational service. This relationship can be expected because a larger student body enables an institution to deliver its services more cost-effectively on a per-student basis, thereby potentially reducing the cost of education for the students. Research has shown that even in traditional face-to-face contexts, larger universities charge lower tuitions and experience lower costs of service delivery per student due to their size (Laband \& Lentz 2003; Patterson, 2000; Rumble, 2009).

While past research supports the negative relationship between institution size and cost of educational delivery, research on the effects of the size of student population on tuition in the specific context of online programs is nonexistent. On the one hand, it can be expected that larger brick-and-mortar institutions can experience cost savings due to their size, which can transfer over to the side of their operations dealing with online programs. On the other hand, it is possible that larger institutions have a greater degree of brand recognition and can therefore charge higher tuition levels. The net effect of student population size on the tuition for online MBA programs can therefore not be definitively determined based on past research, and the nature of this relationship needs to be empirically explored.

\section{Student-to-Faculty Ratio}

One of the factors that has been known to affect the cost of higher education is the ratio of the number of students to the number of faculty, known as the student-to-faculty ratio (STFR). In general, educational institutions that have a low student-to-faculty ratio demand higher tuition levels (Bound \& Turner, 2007; Johnson \& Turner, 2009). This is because programs with a low STFR can deliver a greater degree of personalization to their students, as each faculty 
member would be able to attend to the needs of a smaller number of students (Orellana, 2006). The higher level of quality of education that may be perceived to be associated with such a personalized learning environment can help justify higher tuition levels.

In addition, schools that have a low STFR often experience higher costs of educational delivery on a per-student basis, since the same faculty member would be responsible for teaching a small number of students, and as a result a greater number of faculty would need to be employed in order to serve the student population. Despite these expectations, the extent to which the student-to-faculty ratio can influence tuition in online settings has not been studied in past research. In an online environment, due to the use of technology to facilitate instruction, and the distant form of student-faculty interactions, the level of personalization is less evident, compared to face-to-face settings (Christensen $\&$ Horn, 2016). For example, the degree of one-on-one contact with the faculty member is lower since much of the education may be assisted by support staff, teaching assistants, automated teaching modules, and other asynchronous means of teaching that may not require direct one-on-one involvement with the professor. Therefore, while one may expect a positive relationship between STFR and tuition levels for online MBA programs, the degree to which this expectation materializes is an empirical question.

\section{Accreditation Status}

Accreditation is an oversight process in higher education, and especially important in business education (Eaton 2006; Lagrosen, 2017). The attainment of accreditation signals to various stakeholders, that a program has been independently reviewed by external reviewers and meets specific standards of quality. Prospective students often screen their choices of schools based on whether or not the program has been accredited (Cavico \& Mujtaba, 2010; Jewett, 2012; McFarlane, 2014) and employers may also only narrow the scope of their choice of schools for recruiting graduates to those that have accredited programs (Kohlmeyer, Seese \& Sincich, 2011). While it is possible that having an online program accredited will be viewed in greater regard by the stakeholders (e.g., students and employers), the relationship between accreditation and current tuition levels for online MBA programs needs further study.

\section{Private versus Public}

From a segmentation perspective, private universities target a more affluent population base and are also viewed as more exclusive (Tang, Tang \& Tang, 2015). In contrast, public universities serve the needs of more cost-conscious students and may have tax-payer initiated mandates to make education widely accessible to the general public through affordable tuitions. As a result, public universities' ability to raise tuitions is constrained (Basch, 1997). Past research has shown that the tuition level for public universities is generally lower than for private universities in the United States and abroad (Smith \& Bramble, 2008). In the context of online MBA programs, it may therefore be expected that the tuition levels for programs offered by private universities would be greater than the tuition levels for public universities.

\section{Residency Requirement}

The notion of distance delivery of education is implemented to varying degrees in online MBA programs. Some programs require that students attend on-campus activities, such as residential workshops at some point during their program, while others do not have such residency requirements. From a pedagogical perspective, the motivation behind having an on-campus residency requirement is that it enables the students to experience the campus environment of the university, personally interact with their faculty, and build a stronger sense of connection with fellow students (Ponzurick, Russo-France \& Logan, 2000). Despite these benefits, residency requirements demand greater resources from the institution in terms of providing the facilities, staff and faculty to host on-campus residency events for online students. It may therefore be expected that online MBA programs that have a residency requirement would have higher tuition levels compared to those that do not have residency requirements.

\section{GMAT Test Requirement}

Entry requirements to MBA programs can form a hurdle for some prospective students. One of these hurdles in graduate business education is the requirement for taking the GMAT (Graduate Management Admissions Test) which requires considerable effort in exam preparation. Studies on GMAT as a predictor of MBA performance indicate that 
while the GMAT verbal score is positively correlated with graduate GPA level of MBA students, it is in fact the prospective MBA student's undergraduate GPA and work experience which are the stronger predictors of academic performance in an MBA program (Fairfield-Sonn, Kolluri, Singamsetti \& Wahab, 2010; Kass, Grandzol \& Bommer, 2012; Pratt, 2015; Hammond, Cook-Wallace, Moser, \& Harrigan, 2015). Waiving the GMAT requirements for applying to an online MBA program may encourage a greater number of applications, resulting in higher demand for the program and the ability of the program to charge higher tuition levels. This is because programs that are less demanding in terms of entry requirements are more likely to receive large number of applications. The resulting higher level of demand for a program can possibly enable an institution to raise its tuition levels.

Despite the positive effects that waiving the GMAT requirement may have on tuition levels, as argued above, negative effects may also be expected from such a waiver. This is because more prestigious programs often have strict standards for acceptance (Christensen \& Horn, 2016). By not requiring the GMAT from prospective students upon applying to the program, the program may send a signal to a variety of stakeholders that it is of lower quality. It is therefore possible that waiving GMAT requirement will lower perceptions of value in the program from the perspectives of applicants as well as employers who recruit their future employees among graduates of a given program. The net effect may be a lowering of the brand equity of the program which can negatively affect the amount of tuition the program could demand of students.

\section{RESEARCH QUESTIONS}

Based on the discussion presented above, the objective of this paper is to examine the following research questions:

1. What is the impact of student population size on the tuition for online MBA programs?

2. How does the student-to-faculty ratio at a university affect the online MBA program tuition levels?

3. Are there differences in the online MBA tuition levels, based on the accreditation status of an online MBA program?

4. Are the online MBA tuition levels different for private versus public universities?

5. Are the online MBA tuition levels different for programs that have on-campus residency requirements versus those that do not have residency requirements?

6. How does the waiving of GMAT requirements affect the tuition for an online MBA program?

\section{METHODOLOGY}

\section{Data}

The data for this study were collected from public sources that provide detailed information on online MBA programs, including tuition levels, university characteristics (e.g., size of student population, student-to-faculty ratio), accreditation status and application and residency requirements. The data were captured from two sources: onlinemba.com and Integrated Postsecondary Education Data System (IPEDS). From onlinemba.com web site, information such as location, funding source, GMAT requirement, residency requirement, estimated tuition, minimum program length, accreditation agency, student population, level of urbanization, and student to faculty ratio were collected. From IPEDS, information such as educational level, and degree-granting status were collected. This method of data collection, and the use of established publically accessible secondary data sources for analysis of relationships of interest in understanding pricing patterns in the marketplace consistent with previous studies (CITES: a couple of citations of past studies). The data collection took place in November 2017. A total of 149 programs were identified and used for the purposes of this analysis. Of the 149 programs studies, 87 were private, 20 required oncampus residency visits, and 99 required the GMAT as part of the application process. The average size of the university student population was 10,575 and the average student-to-faculty ratio was 15.4 . The accreditation agencies for the online MBA programs included the following: AACSB (Association to Advanced Collegiate Schools of Business), HLC (Higher Learning Commission), IACBE (International Accreditation Council for Business Education), ACBSP (Accreditation Council for Business Schools and Programs), WASC (Western Association of Schools and Colleges), SACSCOC (Southern Association of Colleges and Schools Commission on Colleges), NEASC (New England Association of Schools and Colleges), with AACSB accounting for the largest group. 


\section{RESULTS}

\section{Bivariate Analyses}

Below, we will first examine the relationship between tuition levels and each of the research variables of interest, one variable at a time. For the research variables of interest that are categorical, the average values for each level of the variable are computed, and then t-tests are used to determine if any of the observed differences are statistically significant. For continuous research variables, correlation analysis is used to determine if a relationship between tuition level and the variable of interest exists. The use of t-tests for categorical variables and correlation analysis for continuous variables is consistent with the norms in bivariate analysis in which the empirical relationship with another continuous variable (e.g., tuition levels) is being tested (Hair, Anderson, Tatham \& Black, 1998; Lehmann, Gupta \& Steckel, 1998). Table 1 shows the different levels of tuition associated with the different levels for the research variables.

Table 1. Average Tuition for Different Levels of the Categorical Variables

\begin{tabular}{|c|c|c|c|}
\hline Variable & & & Significance Test \\
\hline Funding Source & $\frac{\text { Private }}{\$ 31,640}$ & $\frac{\text { Public }}{\$ 25,974}$ & $\mathrm{t}_{147}=3.87 ; \mathrm{p}<.1$ \\
\hline Residency Requirement & $\frac{\text { Required }}{\$ 44,426}$ & $\frac{\text { Not Required }}{\$ 26,935}$ & $\mathrm{t}_{147}=19.46 ; \mathrm{p}<.01$ \\
\hline GMAT Requirement & $\frac{\text { Required }}{\$ 30,164}$ & $\frac{\text { Not Required }}{\$ 27,537}$ & $\mathrm{t}_{147}=0.75 ; \mathrm{p}=0.39$ \\
\hline AACSB Accreditation & $\frac{\text { Yes }}{\$ 34,052}$ & $\$ 2 \frac{\text { No }}{5,489}$ & $\mathrm{t}_{147}=9.30 ; \mathrm{p}<.01$ \\
\hline
\end{tabular}

With respect to the private versus public status of the university, the average tuition for private online MBA programs was found to be $\$ 31,640$, compared to $\$ 25,974$ for public programs. This difference was tested using a t-test and found to be statistically significant $\left(\mathrm{t}_{147}=3.87 ; \mathrm{p}<.1\right)$, suggesting higher tuition levels for private online MBA programs. In terms of on-campus residency requirements, the average tuition for online MBA programs that require on-campus residency visits was $\$ 44,425$, compared to $\$ 26,935$ for programs that do not have an on-campus residency requirement. This difference was tested using a $\mathrm{t}$-test and found to be statistically significant $\left(\mathrm{t}_{147}=19.46 ; \mathrm{p}<.01\right)$, indicating notably lower tuition levels for programs that do not have residency requirements.

The average tuition for online MBA programs that require the GMAT was $\$ 30,164$, compared to $\$ 27,537$ for programs that do not require the GMAT. This difference was tested using a t-test and found not to be statistically significant $\left(\mathrm{t}_{147}=0.75 ; \mathrm{p}=0.39\right)$. In order to determine the effects of accreditation bodies on tuition levels, the online MBA programs were categorized into two groups: those with AACSB accreditation (which accounted for $44 \%$ of the sample), and those without. The average tuition for programs with AACSB accreditation was $\$ 34,052$, compared to $\$ 25,489$ for the remaining programs -- a difference that is statistically significant at the $\mathrm{p}<.01$ level $\left(\mathrm{t}_{147}=9.30 ; \mathrm{p}<.01\right)$.

Two of the research variables of interest are not categorical, but rather continuous: size of the student population at the university, and the student-to-faculty ratio (STFR). For these variable, the Pearson correlation coefficient between tuition and each of the two variables was computed. The correlation between tuition and student population was found to be 0.43 . The positive sign of this correlation indicates that the larger the student body, the higher the tuition. This correlation is statistically significant $(\mathrm{p}<.01)$ and supports the view that larger institutions benefit from their widely recognized name and may be able to charge higher tuition levels. The Pearson correlation between tuition and studentto-faculty ratio was found to be -0.17 . The negative sign of this correlation indicates that programs that have a higher student-to-faculty ratio have lower tuitions. This correlation, though small in magnitude is statistically significant $(\mathrm{p}<.05)$ and suggests that when more students are allocated to professors (hence a higher STFR), the program costs (in terms of the tuition paid by the students) decline. This finding concurs with the view that increased operational efficiency of the institution is passed on to students in the form of lower tuitions. 


\section{Regression Analysis}

While the above analysis examined the individual effects of the various research variables on tuition levels for online MBA program, the combined effects of these variables needed to be further examined in a single analysis using linear regression. Regression analysis is used when a continuous variable (e.g., tuition levels) is being predicted (serving as a dependent variable) by other continuous variables (e.g., student-to-faculty ratio) or categorical variables (e.g., GMAT waiver) expressed using dummy variables (Hair et al. 1998; Lehmann et al. 1998), used as the independent variables. The sign, magnitude and significance of the independent variables would then be indicative of their empirical effects on the dependent variable.

In this regression analysis, tuition was used as the dependent variable. The independent variables were the research variables outlined earlier: GMAT requirement (coded as a dummy variable which takes on a value of 1 if the program application requires the completion of GMAT, and takes on a value 0 if the GMAT requirement is waived), on-campus requirement (coded as a dummy variable which takes on a value of 1 if the program requires on-campus residency visits, and takes on a value of 0 otherwise), AACSB accreditation (coded as a dummy variable which takes on a value of 1 if the program is accredited by AACSB, and 0 otherwise), and private status of the university (coded as a dummy variable which takes on a value of 1 if the university is a private institution, and a value of 0 otherwise). In addition to these predictors, the two continuous measures, namely student population and student-to-faculty ratio, were also used as predictors in the regression analysis. Before running the regression analysis, it was important to establish that multi-collinearity is not a concern. The condition number for the set of predictor variables was computed and found to be 3.28, indicating that multicollinearity is not a concern (Hair et al. 1998).

The regression analysis achieves a high degree of model fit $\left(\mathrm{R}^{2}=0.55\right)$ and is statistically significant $\left(\mathrm{F}_{6,139}=28.64\right.$; $\mathrm{p}<.01$ ). The regression analysis results (Table 2 ) indicate that, consistent with the correlation analysis reported earlier, the size of the student population is positively related to tuition levels. This is evident in the positive and statistically significant $(\mathrm{p}<.01)$ coefficient for student population. Also consistent with the results of the correlation analyses reported earlier, the student-to-faculty ratio negatively impacts tuition levels $(\mathrm{p}<.01)$. The private status of a university contributes to tuition levels at statistically significant levels $(\mathrm{p}<.01)$. This is consistent with the bivariate analyses reported above, as well as earlier studies in this field dating nearly a decade ago (Estelami \& Rezvani 2011; Smith \& Bramble, 2008).

Table 2. Regression Analysis Results (Dependent Variable: Tuition)

\begin{tabular}{l|c|c|c}
\hline \multicolumn{1}{c}{ Variable } & Parameter Estimate & t Value & Pr $>|\mathbf{t}|$ \\
\hline Intercept & 7,925 & 1.35 & 0.1807 \\
\hline Private University & 23,677 & 7.28 & $<.0001$ \\
\hline GMAT Requirement & 2,604 & 1.11 & 0.2693 \\
\hline Residency Requirement & 4,873 & 1.47 & 0.1425 \\
\hline AACSB Accreditation & 13,529 & 4.58 & $<.0001$ \\
\hline Student Population & 0.988 & 9.02 & $<.0001$ \\
\hline Student-to-Faculty Ratio & -742 & -2.73 & 0.0072 \\
\hline
\end{tabular}

The regression analysis results indicate that the requirement for on-campus residency visits does not affect tuition levels. The results also indicate that the GMAT requirement does not affect tuition levels $(\mathrm{p}>.1)-\mathrm{a}$ finding that is also consistent with the insignificant effect which had been observed in the bivariate analysis reported above. Also consistent with the bivariate analyses, AACSB accreditation of a program is found to have a positive and significant effect on tuition levels.

\section{DISCUSSION}

The online MBA degree is growing in its credibility and public acceptance, and earning an MBA using distance methods is becoming more acceptable by key stakeholders such as employers, prospective students, university administrators and accreditation agencies (Eaton, 2006; Lagrosen, 2017). Akin to the growth of public acceptance of the online MBA degree, a growing number of online MBA programs offerings is also driving up the cost of education. In light of these trends, it is critical to understand the factors that affect the tuition for online MBA programs. For institutions that are currently offering online MBA programs, such an understanding of the pricing may help assess Copyright by author(s); $\underline{\text { CC-BY }}$ 
the market competitiveness of their programs; similarly, for institutions that are planning to offer online MBA programs, such pricing knowledge may provide guidance on enrollment expectations. Understanding the drivers of online MBA tuition is an equally important concern to regulators concerned about the pricing, recruitment and placement practices used by online MBA programs. Hence it is of central importance to many stakeholders to understand what factors determine the tuition for online MBA programs.

The results of this study demonstrate that online MBA tuitions are closely linked to underlying characteristics of the program, such as its residency and GMAT requirements, as well as institutional characteristics such as the size of the university's student population and the student-to-faculty ratio. The regression analysis results discussed earlier provide a formal framework for developing such relationships using the coefficients for the various research variables profiled in this study. Based on the linear equation extracted from the regression analysis, online MBA programs can determine what the market-based tuition level for their program should be. The coefficients from the regression analysis suggest the following formula for determining the market-based tuition level for a program, based on its underlying characteristics:

$$
\begin{aligned}
\text { Tuition }= & 7,925+23,677(\text { Private })+2,604(\text { GMAT requirement dummy })+ \\
& .872(\text { On campus requirement dummy })+13,529(\text { AACSB accreditation dummy })+ \\
& 0.98(\text { Student population })-742(\text { Student to faculty ratio })
\end{aligned}
$$

The above equation enables program administrators to self-evaluate the tuition levels for the online MBA program they are offering to the marketplace. By including in the above regression-based formula, the values of the characteristics of a given program, the market-based tuition level can be established, and compared to the actual tuition level charged by a given school.

Such analysis would allow the program administrators to establish if a given online MBA program is overpriced or underpriced. Both cases of under- and over-pricing for a given online MBA program may require further attention. Underpricing indicates tuitions that are below market expectations, given the program's characteristics. The result of this is potential revenue loss and lower profitability for the program. Overpricing would reflect scenarios in which the tuition charged for an online MBA program exceeds market norms, potentially making the program less attractive to prospective students. Assessment of the incidents of overpricing or underpricing can help program administrators determine if the program characteristics are in tune with the identity, mission and positioning of the program, as communicated with stakeholders such as prospective students, alumni and regulators. For example, if a program aimed at serving underprivileged populations is determined to be over-priced, downward adjustments in tuition levels may be called for. Such directional adjustments are critical in ensuring that an online MBA program is providing students with the level of value that is consistent with its promises and mission.

Several limitations of this study need to be acknowledged. The data for this study was limited to the 149 online MBA programs that could be identified through the secondary data sources used. Use of other data sources to identify other online MBA programs would expand the scope of this study and potentially enable empirical examination of a larger array of variables that may affect online MBA tuition levels. Future studies can also expand this line of research by examining the determinants of tuition levels for other graduate business programs, such as masters and certificate programs. Furthermore, while the GMAT waiver, which is a categorical variable, was used as a predictor in the empirical analysis presented, the use of average GMAT scores for each program may have shed additional light on the effects of the standard test profile of prospective students. Unfortunately, this data element was not available, especially in light of the fact that nearly one-third of the programs profiled did not have a GMAT requirement altogether. Future study can also focus on the factors that affect tuition levels for non-business online programs, using the research design and methodology demonstrated in this study. Future research can also examine the differences in students' return on investment (ROI) for the programs, as for example measured by ratio of graduates' salaries to the tuitions they pay. Such a line of inquiry would help shed light on the value proposition offered by online MBA programs, not just in terms of the tuitions charged, but rather by the career and financial prospects attributed to the completion of the program. 


\section{CONCLUSION}

This study demonstrated a systematic approach for determining the drivers of the tuition charged by online MBA programs. This systematic approach relies on the analysis of the underlying program features and institutional characteristics to help determine what drives tuition levels. The resulting analysis demonstrated that the tuition for online programs is most affected by size of the university's student population, the status of the university as a private educational institution, accreditation status, and the student-to-faculty ratio. Understanding the role that these, as well as other factors, play in determining tuition levels is critical in establishing how to improve the value proposition in an online MBA program, with eventual benefits for both the students and the universities offering these programs.

\section{AUTHOR BIOGRAPHIES}

Hooman Estelami is a professor of marketing at the Gabelli School of Business, Fordham University in New York. $\mathrm{He}$ is the author of six books: Marketing Financial Services; Marketing Turnarounds; The Routledge Companion to Financial Services Marketing; Predictors of Victory and Injury in Mixed Martial Arts Combat; Cases in Financial Services Marketing, and Frontiers of Distance Learning in Business Education. He is the editor of the International Journal of Bank Marketing, and previously served as the associate editor of the Journal of Product and Brand Management. His research has appeared in a wide range of journals including: International Journal of Research in Marketing, Journal of the Academy of Marketing Science, Journal of Financial Services Marketing, Journal of Retailing, Journal of Business Research, Journal of Service Research, Journal of Product and Brand Management, Journal of Consumer Behavior, Journal of Promotion Management, Journal of Marketing Education, American Journal of Business Education, and Marketing Education Review. Email: estelami@fordham.edu

Zixin Mao is an Ed.D. candidate in Educational Leadership, Administration, and Policy at the Graduate School of Education, Fordham University. He is the Associate Director of Information and Faculty Technology at the Gabelli School of Business and teaches Web Analytics as an adjunct instructor in the Information Systems area. He received his M.S. in Business Analytics at Fordham University and B.S. in Computer Science at Penn State University. His research areas are in online learning, organizational learning, and technology-mediated change.

\section{REFERENCES}

Basch, D. L (1997). Private colleges' pricing experience in the early 1990s: The impact of rapidly increasing college funded grants. Research in Higher Education, 38(3), 271-296.

Bound, J., \& Turner, S. (2007). Cohort crowding: How resources affect collegiate attainment. Journal of Public Economics, 91(5/6), 877-899.

Byrd, J., Roufagalas, J., \& Mixon, P. (2015). Tuition Sensitivity in Online Education, Journal of Economics and Economic Education Research, 16(3), 25-41.

Christensen, C. M., \& Horn, M. B. (2016). Disrupting class: How disruptive innovation will change the way the world learns. New York: McGraw-Hill.

Cavico, F. J., \& Mujtaba, B. G. (2010). An Assessment of Business Schools' Student Retention, Accreditation, and Faculty Scholarship Challenges, Contemporary Issues in Education Research, 3(1), 107-118.

Eaton, J. S. (2006). Accreditation and recognition in the United States. Washington, D.C.: Council for Higher Education Accreditation.

Estelami, H., \& Rezvani, Z. (2011). Structural and perceptual determinants of the price of online business education. Journal of Product and Brand Management, 20(2), 158-165.

Fairfield-Sonn, J. W., Kolluri, B., Singamsetti, R., \& Wahab, M. (2010). GMAT and other determinants of GPA in an MBA Program. American Journal of Business Education, 3(12), 77-85.

Hair Jr., J. E., Anderson, R. E., Tatham, R. L., \& Black, W. C. (1998). Mutivariate data analysis. Upper Saddle River, NJ: Prentice Hall.

Hammond, K. L., Cook-Wallace, M. K., Moser, E. R., \& Harrigan, R. L. (2015). Traditional MBA admissions criteria and graduate school success: The importance of GMAT scores and undergraduate GPA as predictors of graduate business school performance. Academy of Educational Leadership Journal, 19(2), 67-75.

Jewett, J. (2012). A survey of students' perceptions of business accreditation and their rationale in selecting and MBA program. Doctoral Dissertation: Saint Louis University.

Johnson, W. R., \& Turner, S. (2009). Faculty without students: Resource allocation in higher education. The Journal of Economic Perspectives, 23(2), 169-189.

Kass, D., Grandzol, C., \& Bommer, W. (2012). The GMAT as a predictor of MBA performance: Less success than meets the eye. Journal of Education for Business, 87(5), 290-295.

Copyright by author(s); $\underline{\text { CC-BY }}$ 
Kohlmeyer III, J. M, Seese, L.P., \& Sincich, T. (2011). Online versus traditional accounting degrees: Perceptions of public accounting professionals. Advances in Accounting Education: Teaching and Curriculum Innovation, 12, 139-165.

Laband, D. N., \& Lentz, B. F. (2003). New estimates of economies of scale and scope in higher education. Southern Economic Journal, 70(1), 172-188.

Lagrosen, S. O. (2017). Quality through accreditation. International Journal of Quality and Service Sciences, 9(3/4), 469-483.

Lehmann, D. R., Gupta, S., \& Steckel, J. H. (1998). Marketing research. New York: Addison-Wesley.

Liberman, M. (2018, April 12). Blended is best. InsideHigherEd, Retrieved from: https://www.insidehighered.com/digitallearning/article/2018/04/12/online-programs-can-contribute-better-outcomes-lower-costs-and

McFarlane, D. A. (2014). Contemporary barriers to excellence in business education. Journal of Business Studies Quarterly, 6(2), $125-136$

Nelson, C. (2016, October 17). Continued growth in accessibility of AACSB-accredited online degrees. AACSB Blogs. Retrieved from http://aacsbblogs.typepad.com/dataandresearch/2016/10/continued-growth-in-accessibility-of-aacsbaccredited-online-degrees.html.

Orellana, A. (2006). Class size and interaction in online courses. The Quarterly Review of Distance Education, 7(3), 2006, 229248.

Patterson, G. (2000). Findings on economies of scale in higher education: Implications for strategies of merger and alliance. Tertiary Education and Management, 6(3), 259-269.

Ponzurick, T. G., Russo-France, K., \& Logan, C. M. (2000). Delivering graduate marketing education: An analysis of face-toface versus distance education. Journal of Marketing Education, 22(3), 180-187.

Poulin, R., \& Straut, T. (2017). WCET Distance Education Price and Cost Report. Retrieved from: https://wcet.wiche.edu/sites/default/files/Price-and-Cost-Report-2017_0.pdf

Pratt, W. R. (2015). Predicting MBA student success and streamlining the admissions process. Journal of Education for Business, 90(5), 247-254.

Rumble, G. (2009). The costs and economics of open and distance learning. London: Kogan Press.

Smith, M. J., \& Bramble, W. J. (2008). Funding of distance and online learning in the United States, in W. J. Bramble and S. Panda (eds.). Economics of Distance and Online Learning: Theory, Practice and Research. New York: Routledge: 88106.

Staumsheim, C. (2017, February 17). Online Education Costs More, Not Less. InsideHigherEd, Retrieved from: https://www.insidehighered.com/news/2017/02/17/study-challenges-cost-and-price-myths-online-education

Tang, T. L, Tang, D. S., \& Tang, C. S. (2015). College tuition and perceptions of private university quality. The International Journal of Education Management, 18(4/5), 304-316.

Wang, S. (2015). Online vs. on-campus: An analysis of course prices of U.S. educational institutions. Online Journal of Distance Learning Administration, $18(2)$. 
NOTES 